\title{
Debating in EFL Large Classes
}

\author{
By \\ Israa Ismail Al-Sayed Ismail*
}

\section{Introduction}

Many developing countries are battling the problem of large classes. Todd (2006) stated that "large classes are the reality for most English language teachers". Many researchers and methodologists find it difficult to define large classes. Bahanshal (2013) indicated that finding a definition to an idealistic class size which could be applicable in almost all teaching and learning environment tends to be difficult. Also, Thang (2016) asserted that it appears that there was not a commonly accepted definition of a large class in the literature.

For instance, large classes in primary and secondary schools in most of the cases are ranging from 25 to 30 students in the United Kingdom; If the number of students is $\mathbf{3 0}$ or more, these are called super large classes which require teacher assistants who are hired to assist the teachers in those large classes (Blatchford et al., 2007; Pedder, 2006).From 71 to over 100 in Uganda, Haiti and other developing countries are considered large classes (O'sullivan, 2006; Renaud, Tannenbaum and Stantial, 2007; Shamim et al., 2007). From 24 to 25 in Norway and the Netherlands (Ozerk, 2001) are considered large classes. Todd (2006) showed that all the authors in Thailand agree that large classes have at least 40 to 60 students. In Egypt, Al Hadi (1995) stated that small classes range from 22 to 34 . So in Egypt, over 34 students in the class is considered large. Hence, there is no agreement in the literature as to what the optimum number of students in a class should be.

Large class size is considered one of the most effective factors that presumably would make it difficult to give all the learners chances to practice the target language. Many teachers also claim that having a large class prevents them from doing what they want to do to help their learners make progress in developing their language proficiency (Norton; 2001).

A school classroom in many parts of the world including Egypt,

*A research derived from a master thesis under supervision of:

Prof. Fatma Sadek Mohamed / Prof. Taher Mohammad Al-Hadi

* A teacher of English in I smailia 
have become progressively larger. That increase has a negative effect on the educational process, teachers, and students. As seen before, the literature allude that large classes are considered problematic. The also affect on the students participation especially in speaking lessons as there is usually little time for each student to share.

Language is a means of communication, through which people convey messages, transfer information, and express their thoughts, emotions, ideas and points of view. Nowadays, English language is one of the most important languages, and it may be the most spoken language in the world. It also becomes the official language in many fields as business, policy, education, modern technology and many other fields. So learning English has become a must and it is necessary for our students to learn how to communicate in it. In Egypt, it is taught to students from primary stages to university.

To many researchers, experts, and specialists, speaking is the most important skill as its goal is to communicate effectively and that is what any language learners seek for. Hornby (2000) (as cited in Rabu, 2013) defined speaking as "the ability to perform the linguistics knowledge in the actual communication". Ur (2009) claimed that of all four skills (listening, reading, speaking and writing), speaking seems intuitively the most important. In addition, in learning a language not your own language, you will find that speaking is the most difficult skill to master. Thronbury (2005) stressed that there is no wonder that speaking represents a real challenge to most language learners.

Teaching speaking is very important and also seems to be difficult but with the problem of large classes that Egypt faces; it is seemed to be a challenge. The problem in practicing speaking in the classroom is very common. Many researchers tried to solve it adopting different techniques and strategies. One of these strategies is debate.

Debate is very effective strategy in teaching speaking skill. According to O'Mallay and Pierce (1997), debate can present opportunities for students to engage in using extended chunks of language for a purpose. Also Carter and Carthey (1997) stated that debate is one of the most effective speaking activities which can encourage students to improve their communication.

Debate can be defined as "an excellent activity for language learning because it engages students in a variety of cognitive and linguistic way. It is providing meaningful listening, speaking and writing practice (Krieger, 2005, p.25)." Bradshaw and Lowenstein (2017) defined debate 
as a strategy that promotes students' interaction and involvement in course. Also, Mumtaz and Latif (2017) claimed that "debate" is a teaching strategy to enhance communication skills, improve critical thinking and problem-solving skills and to develop confidence, respect, and team work.

In this study the researcher attempted to investigate the effectiveness of a debate-based strategy for improving some speaking skills among the secondary school EFL students in large classes in Egypt.

In order to confirm this claim, a pilot study was conducted. Its purpose was to assess speaking performance of some secondary schoolers in terms of their speaking performance. The results of the pilot study are displayed below:

1. Students lack of accomplishing some communicative functions according to goals $(100 \%)$.

2. Students lack of using some strategic devices to enhance the clarity of the message $(100 \%)$.

3. Students lack of note taking in conversations $(\mathbf{1 0 0 \%})$.

4. Students lack of conveying links between events and communicative relations $(83.3 \%)$.

5. Students lack of giving appropriate exemplification to support the point in hand $(50 \%)$.

6. Students lack of expressing supported opinions and personal views (66.8\%).

8. Students lack of using emphasizing key words (100\%).

9. Students lack of expressing the same idea in different words $(50 \%)$.

10. Students lack of providing a context interpreting the meaning of words $(\mathbf{1 0 0 \%})$.

DBS was designed for determining the impact of a Debate-Based Strategy in developing secondary stage learners' some speaking skills in EFL large classes. The speaking skills which would be developed through the strategy are: accomplishing some communicative function, using some strategic devices to enhance the clarity of the message, giving appropriate exemplification to support the point in hand, expressing supported opinions and personal views, using emphasizing key words, expressing the same idea in different words, using cause and effect relations, and using a sound inference. The researcher decided on these skills because of:

1. The national standards

2. Analysis of assigned textbook

3. Review of literature 
4. Pilot study to assess the students' performance

5. The researcher's own observation

Problem of the study

Based on the review of literature and results of the pilot study, the problem of the current study was stated that the EFL secondary schoolers could not practice some speaking skills due to their large classes. Therefore, a suggested strategy based on debate was adopted to develop the target speaking skills in large classes.

Questions of the study

The problem above can be translated into the following questions:

1. What are the English language speaking skills needed for EFL secondary schools students?

2. How far do secondary school EFL students' master those speaking skills?

3. What are the features of a debate-based strategy that may improve some speaking skills?

4. What is the effect of the proposed debate-based strategy on improving those skills?

Delimitations of the study

This study was delimited to:

1. Secondary school EFL students in large classes of first secondary school stage EFL students at Al-Salam Secondary School for Girls in Ismailia. There were reasons behind selecting this sample. First, they have a shortage in the speaking skills. Second, their language competence is high enough to acquire those speaking skills. Third, their textbook has some topics that are controversial and suitable for debate.

2. Some speaking skills: (Accomplishing some communication functions, using strategic devices, taking notes, conveying links, expressing exemplification, expressing opinions, using key words, expressing same idea, and providing a context.)

3. Using two techniques of debate strategy.

Methods and Procedures

Design and participants

The design used in the present study was the one group pre-post test quasi- experimental design. The researcher tested all the participants of the study on the speaking skills that are reflected in debate skills before the experiment. Finally, the study group received the proposed program (Debate-based strategy). Upon the completion of the 
experiment, the participants were post tested. Each speaking skills test (pre/post) was evaluated to investigate the differences between pre and post-test mean scores.

The most popular and rigorous form of probability sampling form of a population is simple random sampling. Through this technique, any individual has an equal probability of being selected from the population. The sample of this study was drown randomly from firstyear secondary stage EFL learners at Al-Salam Secondary School for girls in Ismailia during the 2016/ 2017 school year. It was composed of thirty nine learners $(N=39)$. They all ranged between 16-18 years of age.

There were some reasons behind selecting the first year secondary school students as a sample for this study. First, they lack the skills required for developing some advanced speaking skills. Second, their language competence is high enough to acquire those speaking skills. Third, their textbook has some topics that are controversial and suitable for debate.

\section{Instruments}

In order to test the hypothesis of the study, two instruments were developed, two Speaking Skills Tests. These instruments were basically based upon a speaking checklist. At the beginning, the initial raw version of speaking skills checklist was submitted to a group of specialists in EFL field as a jury to validate it to arrange those skills in terms of the order of necessity. That is for reaching the final form of needed speaking skills.

1. Speaking Skills Tests

Two equivalent tests were used as a pretest and a posttest in order to measure learners' usage of speaking skills (which are selected and validated) before and after the intervention. Each of the speaking skills test consisted of four controversial and debatable situations and aimed at measuring the performing of some speaking skills. The skills to be judged were: accomplishing some communicative functions, using some strategic devices to enhance the clarity of the message, giving appropriate exemplification to support the point in hand, expressing supported opinions and personal views, using emphasizing key words, providing a context interpreting the meaning of the words, expressing the same idea in different words, using cause and effect relations, and using a sound inference.

Procedures 
The experimental procedures of the present study were executed in the Al-Salam Secondary School for girls in Ismailia during the 2016/ 2017 -school year. The purpose of these procedures was to test the effect of DBS on first- year secondary stage EFL students' speaking test. These procedures were carried out in three consecutive stages: pretesting, implementing DBS for speaking skills, and then post testing. Each of those stages is described in detail as follow:

1. Pretesting

In the beginning of the experimental study, the pretest was administrated to the participants of the study. The purpose was to determine EFL learners' initial level of speaking skills (Appendix A)

2. Implementing Debate-Based Strategy (DBS)

The DBS had been condensed and taught for a month (four periods per weak). It began on the 12th of March and ended on the 4th of April. Some debating techniques were used such as:

1. The Fishbowl Debate

Randomly select a handful of students to come sit in front of the classroom in a half-circle facing the students. Pose a question or a statement to those selected students and ask them to discuss it. The rest of the classmates ask a question to the panel or take turns taking their spot in the fishbowl, but they are not allowed to speak otherwise. This format is used when students have prior knowledge about the topic.

2. Ball-Toss Debate

Students are given a topic and must take a side. Each student goes to the side of the classroom where their position is either for or against the topic. Move desks so that each side is facing each other. Have students sit on their desks and take turns tossing a ball to discuss their position on the topic. Only the student with the ball can speak. This debate is just like the mum-ball, except students are using it to debate an issue.

\section{Description of DBS}

DBS consists of an introductory session and three teaching units; each unit consists of three sessions. All are related to each other. All of them aim to get students master the debate strategy to improve their speaking skills.

2. Posttesting

Upon the completion of the experiment, the study group was posttested. The researcher evaluated gain mean scores for the study 
group so that she could determine whether there was a reliable change between the pretest and posttest. For this purpose, she employed t-test and effect size (Appendix B).

\section{Results and discussion}

This part includes the statistical analyses performed on the data gathered from the pre- and posttests as well as the results found by the researcher in this study in light of the hypothesis of the study and the discussion of these results in light of previous studies, and the theoretical background. All the data collected were analyzed using the Statistical Package for the Social Sciences (SPSS).

Table (1): Comparison of the study group's mean scores on pre and No. $=39$ post tests of speaking skills

\begin{tabular}{|c|c|c|c|c|c|}
\hline \multicolumn{2}{|c|}{ Speaking skill } & Mean & SD & t-value & Sig. \\
\hline \multirow{2}{*}{$\mathbf{C F}$} & Pre & 0.35 & 0.51 & \multirow[t]{2}{*}{-25.16} & \multirow[t]{2}{*}{$\mathbf{0 . 0 0}$} \\
\hline & Post & 2.33 & 0.40 & & \\
\hline \multirow{2}{*}{ SD } & Pre & 0.85 & 0.58 & \multirow[b]{2}{*}{-16.33} & \multirow[t]{2}{*}{0.00} \\
\hline & Post & 2.41 & 0.36 & & \\
\hline \multirow{2}{*}{$\mathbf{A E}$} & Pre & 0.35 & 0.56 & \multirow[t]{2}{*}{-23.33} & \multirow[t]{2}{*}{0.00} \\
\hline & Post & 2.56 & 0.40 & & \\
\hline \multirow{2}{*}{ SO } & Pre & 0.54 & 0.63 & \multirow[t]{2}{*}{-19.77} & \multirow[t]{2}{*}{0.00} \\
\hline & Post & 2.49 & 0.45 & & \\
\hline \multirow{2}{*}{ KW } & Pre & 0.10 & 0.37 & \multirow[t]{2}{*}{-26.38} & \multirow[t]{2}{*}{0.00} \\
\hline & Post & 1.90 & 0.33 & & \\
\hline \multirow{2}{*}{ DI } & Pre & 0.22 & 0.46 & \multirow[t]{2}{*}{-25.14} & \multirow[t]{2}{*}{$\mathbf{0 . 0 0}$} \\
\hline & Post & 2.47 & 0.36 & & \\
\hline \multirow{2}{*}{ CI } & Pre & 0.19 & 0.48 & \multirow[t]{2}{*}{-22.08} & \multirow[t]{2}{*}{0.00} \\
\hline & Post & 2.22 & 0.48 & & \\
\hline \multirow{2}{*}{$\mathbf{C E}$} & Pre & 1.17 & 0.55 & \multirow[t]{2}{*}{-16.39} & \multirow[t]{2}{*}{0.00} \\
\hline & Post & 2.86 & 0.26 & & \\
\hline \multirow{2}{*}{ SI } & Pre & 0.00 & $\mathbf{0 . 0 0}$ & \multirow[t]{2}{*}{-20.30} & \multirow[t]{2}{*}{0.00} \\
\hline & Post & 1.74 & 0.54 & & \\
\hline \multirow{2}{*}{ Overall } & Pre & 3.75 & 1.92 & \multirow[t]{2}{*}{-54.91} & \multirow[t]{2}{*}{0.00} \\
\hline & Post & 20.99 & 1.63 & & \\
\hline
\end{tabular}

Since the skills are expressed in long phrases that can not be easily injected in the table some abbreviations are used representing those skills as follows: 
$\mathrm{CF}=$ accomplishing some communicative functions according to goals, $\mathrm{SD}=$ using some strategic devices to enhance the clarity of the message, $\mathrm{AE}=$ giving appropriate exemplifications to support the point in hand, $\mathrm{SO}=$ expressing supported opinions and personal views, $\mathrm{KW}=\mathrm{using}$ emphasizing key words, DI= expressing same idea in different words, $\mathrm{CI}=$ providing a context interpreting the meaning of words, $\mathrm{CE}=$ using cause and effect relations, $\mathrm{SI}=$ using a sound inference

The main hypothesis stated that there would be statistically significant differences between the mean score of the study sample on the pre speaking test and the post speaking test in favor of the post test. The findings are presented in the following table.

Table 2: Comparing the study participants' level on pre and post speaking skills tests

\begin{tabular}{|l|c|c|c|c|c|l|}
\hline & Test & N & Mean & S.D & t-value & \multicolumn{1}{|c|}{ Sig • } \\
\hline \multirow{2}{*}{ Overall speaking skills } & Pre & 39 & 3.75 & 1.92 & \multirow{2}{*}{-54.91} & \multirow{2}{*}{0.00} \\
\cline { 2 - 6 } & Post & 39 & 20.99 & 1.63 & \\
\hline
\end{tabular}

This table shows the participants' level of overall speaking test before the intervention (DBS). The total score of the speaking test equal 108 points and $M_{1}=3.75$. It also shows the participants' level of overall speaking test after the intervention (DBS). The total score of the speaking test equals 108 points and $M_{2}=20.99$. The comparison between the percentages participants' level of overall speaking skills before and after the intervention revealed that the learners' level of target speaking skills enhanced due to the proposed debate-based strategy (DBS).

As shown from the table, the resulting $t$-value is (54.912) which is significant at 0.01 . Thus, the main hypothesis is confirmed, indicating that debate-based strategy had a positive impact on the study group's speaking skills which means that the results may be attributed to the proposed strategy of the present study.

As the strategy was launched, students step by step began to enjoy debates which helped them to be motivated and creative. Thus, the positive attitudes towards debates appeared. And this agrees with Stewart and Pleisch (1998) study which concluded that students enjoyed debating exercises and improving their speaking skills. Besides, classroom debate could also encourage cooperation and teamwork. 
A debate not only improves students' speaking skills in large classes but also, gave them a great opportunity to participate effectively and speak in a confident way to share their ideas and thoughts with their friends. This finding is in line with Zaki (2015) who used debate-based program to develop speaking skills of some engineering students. This stressed that debates maximize the learning outcomes and help achieve the goals of the educational process, encourage creativity and debater students can be more lively and gain more confidence (Somaj, 2015). Such a view is stressed by Arung and Jumardin (2016) who found that the implementation of debate in teaching speaking was successful, because debate is an interesting activity where students have a lot of opportunity to practice speaking in speaking class.

Figure1.

The mean scores of the study group on the overall EFL speaking skills pre-post test

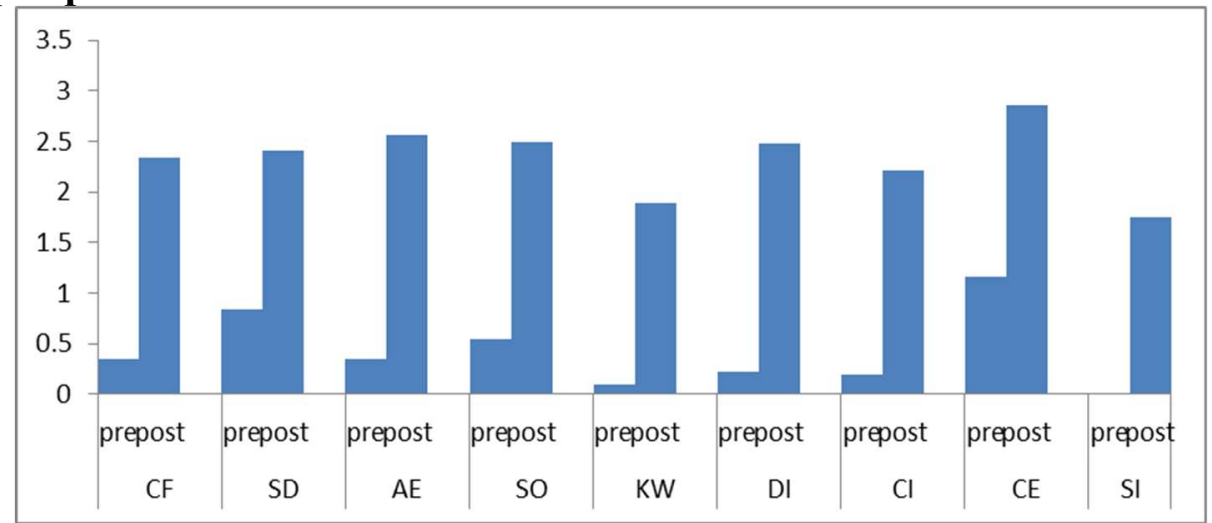

To sum up, the results of this study revealed that DBS developed overall targeted speaking skills as well as each sub skill: accomplishing some communicative functions according to goals, using some strategic devices to enhance the clarity of the message, giving appropriate exemplification to support the point in hand, expressing supported opinions and personal views, using emphasizing key words, expressing same idea in different words, providing a context interpreting the meaning of words, using cause and effect relation, and using a sound inference. In the light of these findings it coud be recommended that debating techniquse shoud be included in the EFL text books in the Eygption context. 


\section{References}

Al Hadi, T. (1995). A Study of some difficulties that encounter secondary school EFL teachers in large classes. Unpublished Master Thesis, Menoufia: Menoufia University

Bahanshal, D. (2013). The effect of large classes on English teaching and learning in Saudi secondary schools. English Language Teaching, 6(11), 49.

Blatchford, P., Bassett, P., Brown, P., Martin, C., \& Russell, A. (2007). The effects of class size on the teaching of pupils aged 7-11 years. School Effectiveness and School Improvement, 18(2), 147-172.

Carter, R., \& Carthey, M. (1997). Exploring spoken language. United Kingdom: Cambridge university press.

Mumtaz, S., \& Latif, R. (2017). Learning Through Debate During Problem-Based Learning: an Active Learning Strategy. Advances in physiology education, 41(3), 390-394.

Norton, B., \& Locastro, V. (2001). Teaching English to large classes; large classes and student learning. TESOL quarterly, 35(3), 493496.

O'malley, J., \& Pierce, L. (1996). Authentic assessment for English language learners: Practical approaches for teachers. New York: Addison-Wesley Publishing Company.

O'Sullivan, M. (2006). Teaching large classes: The international evidence and a discussion of some practice in Ugandan primary schools. International Journal of Educational Development, 26(1), 24-37. Rabu. (2013).The effect of using debate technique toward students' speaking skill at SMA Negeri 5 Kerinci.

Ozerk, K. (2001). Teacher-student verbal interaction and questioning, class size and bilingual students' academic performance. Scandinavian Journal of Educational Research, 45(4), 353-366.

Pedder, D. (2006). Are small classes better? Understanding relationships between class size, classroom processes and pupils' learning. Oxford Review of Education, 32(2), 213-234.

Renaud, S., Tannenbaum, E., \& Stantial, P. (2007). Student-centered teaching in large classes with limted resources. English Teaching Forum, 45(3), 12-17.

Shamim, F., Negash, N., Chuku, C., \& Demewoz, N. (2007). Maximizing learning in large classes: Issues and options. Addis Ababa, Ethiopia: British Council. 
Debating in EFL Large Classes --------- Israa Ismail Al-Sayed Ismail

Thang, H. (2016). How to teach large classes. Available at http://nnkt.ueh.edu.vn/wp-content/uploads/2015/12/11-2015.pdf

Thornbury, S. (2005). How to Teach Speaking. USA: Longman Methodology.

Todd, R. (2006). Why investigate large classes?. KMUTT Journal of Language education, 9(Special issue), 1-12. .

Ur, P. (2000). A Course in Language Teaching: Practice and Theory. New York: Foreign Language Teaching and Research Press. 
الملخص

هدفت هذه الدراسة إلى تطوير بعض مهارات التحدث في الفصول الكبيرة. تم تطوير العلاج على أساس بعض استراتيجيات النقاش. لقياس تأثير استخدام استراتيجية في تحسين مهارات التحدث، تم تطوير اختبارين للمحادثة. وقد تم إجراء هذه الاختبارات لطلاب الصف الأول في مدرسة السلام الثانوية بالإسماعيلية. (عدد = q 9$)$ قبل التدخل وبعده. التذخل تلاعب في الإستراتيجية القائمة على النقاش. أوضحت النتائج وجود فروق ذات دلالة إحصائية بين متوسط الدرجات للاختبار

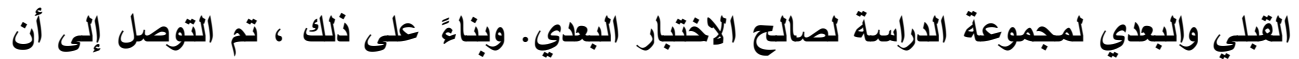
الاستراتيجية المقترحة كان لها تأثير كبير على تطوير مهارات التحدث المستهدفة بين المشاركين. أوصت الدراسة بإمكانية تضمين الإستراتيجية القائمة على المناظرة في دورات تعيين اللغة الإنجليزية كلفة أجنبية في المرحلة الثانوية من أجل إعداد متعلمي اللفة الإنجليزية كلغة أجنبية للمستوى الجامعي.

الكلمات المفتاحية: مناظرة ، مدارس ثانوية في اللغة الإنجليزية كلغة أجنبية ، مهارات التحدث ،

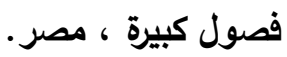

\section{Abstract}

This study aimed to develop some speaking skills in large classes. A treatment based on some debate strategies was developed. To measure the impact of using a strategy in improving speaking skills, two speaking tests were developed. Those tests were administrated to the first year EFL students at Al-Salam Secondary School in Ismailia; $(\mathrm{N}=39)$ pre and post intervention. The intervention manipulated the Debate-Based Strategy. The results revealed that there was a statistically significant difference between the mean scores of the pre and post-speaking test of the study group in favor of the post test. Accordingly, it was concluded that the proposed strategy had a significant effect on developing the targeted speaking skills among the participants. The study recommended that the debate-based strategy may be included in EFL set courses at the secondary stage in order to prepare the EFL learners for the university level.

Key words: Debating, EFL Secondary schools, Speaking Skills, large classes, Egypt. 